\title{
Screening and selection of potential carriers to immobilize Aureobasidium pullulans cells for fructo-oligosaccharides production
}

\author{
C.C. Castro ${ }^{a}, *$, C. Nobre $^{b}$, M.-E. Duprez ${ }^{a}$, G. De Weireld ${ }^{a}$, A.-L. Hantson ${ }^{a}$ \\ a Faculté Polytechnique de Mons, Université de Mons, 20 Place du Parc, 7000, Mons, Belgium \\ ${ }^{\mathrm{b}}$ Centre of Biological Engineering, University of Minho, Campus de Gualtar, 4710-057, Braga, Portugal
}

\section{A R T I C L E I N F}

\section{Article history:}

Received 12 October 2016

Accepted 12 November 2016

Available online 17 November 2016

\section{Keywords:}

Fructo-oligosaccharides

Aureobasidium pullulans

Immobilization

Carriers

\begin{abstract}
A B S T R A C T
Fructo-oligosaccharides (FOS) are non-digestible sweeteners with improved functional and technological properties for food and pharmaceutical industry applications. The immobilization of FOS-producing microorganism's whole cells can be used to improve the production of FOS and so, an accurate choice of the carrier is of crucial importance. Here we present a screening and selection of carriers for immobilization of Aureobasidium pullulans cells with potential for yielding high FOS production. Synthetic, agro-industrial by-products and mineral materials were tested and selected regarding their ability to immobilize cells, as well as their potential to produce FOS, through shaken-flask fermentations. Increased amounts of immobilized cells were found for carriers with higher porosity observed at the microscope, higher water absorption index (WAI) and lower critical humidity point (CHP). Reticulated polyurethane foam was one of the most efficient synthetic carriers immobilizing cells (over $75 \%(w / w)$ of the total cells were immobilized). Also, high FOS production was obtained: FOS concentration, purity and yield increased in 15, 8 and $12 \%(\mathrm{w} / \mathrm{w})$, respectively, as compared to free cells conditions. Although walnut shell had a much lower immobilization efficiency, the high amount of cells grown while using this carrier led to a highest increment of FOS concentration, purity and yield, namely, 27, 10 and 25\% (w/w). Cells immobilization with the selected carriers holds great promise for FOS production on a larger scale.
\end{abstract}

(c) 2016 Elsevier B.V. All rights reserved.

\section{Introduction}

The economic impact of immobilization strategies in bioprocesses has resulted in extensive research and application in a wide range of industrial fields. Microorganisms, microbial enzymes and cells have been immobilized for high-value compounds synthesis, such as: amino acids, organic acids, antibiotics, steroids and enzymes [1]. These compounds have been further used in the food industry, as food and beverage ingredients [2]; in the pharmaceutical industry, for treatment and identification of various diseases [3]; and in the wastewater treatment, for environmental applications [4]. The immobilization of biocatalysts has many advantages, such as: increasing resistance to thermal, chemical and shear forces; promoting their reuse in repeated biosynthesis cycles or continuous process; enabling their recovery from liquid mixtures; and reducing or avoiding inhibition processes $[5,6]$.

Fructo-oligosaccharides (FOS) are sugars with increased commercial interest for food and pharmaceutical industries, mainly

\footnotetext{
* Corresponding author.

E-mail address: cristiana.cordeirodecastro@umons.ac.be (C.C. Castro).
}

due to their prebiotic activity and technological properties (highly soluble, non-digestible, non-cariogenic and low-caloric, highly tolerant to hot and cold, able to improve taste, mouthfeel, texture and food shelf-life [7-9]). FOS can be produced from sucrose by enzymes with both transfructosylating activity, such as fructosyltransferase (EC 2.4.1.9), and hydrolytic activity, such as $\beta$-fructofuranosidase (EC 3.2.1.26). Different microorganisms such as Aureobasidium pullulans, Aspergillus japonicus, Aspergillus niger or Penicillium expansum are the source of such enzymes [10]. The maximum theoretical yield of FOS achieved when using the isolated enzymes is around 55-60\% ( $\left.\mathrm{g}_{\mathrm{FOS}} \cdot \mathrm{g}_{\text {sucrose }}{ }^{-1}\right)[10,11]$, although a slightly higher yield of $64 \%\left(\mathrm{~g}_{\text {FOS }} \cdot \mathrm{g}_{\text {sucrose }}{ }^{-1}\right)$ might be obtained when using the whole cells of the microorganism [12]. The use of the whole microorganism's cells as a biocatalyst also prevents the purification of the FOS-producing enzymes from the cell extracts, enabling the production in only one less expensive and faster step [13-15].

Many attempts have been made to increase the yield and percentage of FOS obtained by fermentation, including: the use of microorganisms in co-culture with the FOS producing cells, as Pichia pastoris [16], Saccharomyces cerevisiae [17] or Zymomonas mobilis $[18,19]$; the use of $A$. niger, in solid-state fermentation 
(SSF), utilizing agro-industrial residues as carriers and/or nutrient sources for the cells [20,21]; the encapsulation of $A$. pullulans cells in calcium-alginate beads [22]; the immobilization of $A$. japonicus to lignocellulosic [20,42], or synthetic materials [23].

Among the different methods for cells immobilization, the entrapment in gels and the use of a supporting carrier were reported as the most suitable for mycelia immobilization [23]. Numerous inorganic and organic materials, with a wide range of pore sizes, have been used as carriers to suit cells immobilization [24]. The main factors that determine the mechanisms of cell immobilization are the cell type and the carrier type, especially whether it is porous or not, which can be evaluated by microscopic analysis [24]. The physicochemical characterization of the carriers, based on the determination of the water adsorption index (WAI) and the critical humidity point (CHP), allows their evaluation as cell immobilizers or as substrate sources under SSF processes [20]. The use of low water content materials, in liquid fermentation or SSF systems, able to absorb water to the matrix, improves fungal growth, yielding higher biomass rates $[20,25,26]$. Also, the use of low-cost and renewable materials, mainly from agro-food processing industry residues and by-products, to immobilize cells, converts the fermentation process into a more attractive economic and environmental alternative $[27,28]$.

The use of a carrier to immobilize cells introduces technological advantages for the bioprocess, by improving the downstream separation and purification procedures and reducing the overall costs of the process. Thus, the main goal of the present work was the selection of a carrier able to immobilize A. pullulans cells, one of the most used microorganisms for FOS production, and reach high yields of FOS with great productivities. Several non-conventional and low-cost carriers, including synthetic, agro-industrial by-products and mineral materials, were studied for further implementation in larger scale fermentation.

\section{Material and methods}

\subsection{Microorganisms and culture conditions}

The fungus used in the experiments was an A. pullulans CCY 271-94. The strain was maintained on Czapeck Dox Agar (Oxoid, UK) plates at $4{ }^{\circ} \mathrm{C}$ and sub-cultured monthly. A concentrated suspension of $A$. pullulans spores was prepared by scraping down the spores, previously grown in Petri plates for 5 days, at $28^{\circ} \mathrm{C}$, with a solution of $0.1 \%(\mathrm{w} / \mathrm{v})$ Tween 80 (Panreac, AppliChem, Spain). The final concentration of the suspension was adjusted to $9 \times 10^{7}$ spores. $\mathrm{mL}^{-1}$, by counting the spores in a Neubauer chamber.

\subsection{Specifications and preparation of the carriers}

The potential of several carriers for A. pullulans cells immobilization was evaluated for a range of synthetic materials, agro-industrial by-products and mineral materials, based on the physicochemical properties of each material. The synthetic materials selected were: S1 - reticulated polyurethane foam (pores diameters $(\phi) \sim 1.5 \mathrm{~mm}$, SKTfilter, China), S2 - reticulated polyurethane foam ( $\phi \sim 1 \mathrm{~mm}$, SKTfilter, China); S3-transformed vegetal cellulose sponge (Scotch Brite, $3 \mathrm{M}$, Spain), S4-transformed vegetal scourer (Scotch Brite, $3 \mathrm{M}$, Spain), S5 - polyester fibre scourer (Emay, China), S6 - Light Expanded Clay Aggregate (LECA) (aggregates size $\sim 4-6 \mathrm{~mm}$, Argex, Belgium), S7 - fibre glass wool ( $\phi=8 \mu \mathrm{m}$, Pyrex, Sigma Aldrich, Belgium), and S8 - polyester staple fibre (Taifor, China). The agro-industrial by-products selected were: A1 - mandarin peel (Citrus reticulata), A2 - banana peel (Musa acuminata), A3 - walnut shell (Juglans), A4 - almond shell (Prunus dulcis), A5 - pistachio shell (Pistacia vera) and A6 - chestnut shell
(Castanea). Finally, the mineral carriers selected were: M1-granular pumice stone (particle size $\sim 4-6 \mathrm{~mm}$, Sigma Aldrich, Belgium) and M2-granular natural mordenite zeolite (particle size $\sim 2-5 \mathrm{~mm}$, $X S V$, China).

The microscopic analysis of each carrier structure was performed using a Digital microscope HIROX KH-8700 using an objective MXG-2500REZ, with a magnification of $35 \mathrm{x}$ using a darkfield illumination.

Carriers were prepared for fermentation according to the methodology described by Mussatto et al. [23], with some adaptations. Firstly, mandarin and banana peels were cut into pieces of $2 \mathrm{~cm} \times 2 \mathrm{~cm}$; the agro-industrial by-products shells were cut in half; foams and fibres were cut into blocs of $1 \mathrm{~cm} \times 1 \mathrm{~cm} \times 1 \mathrm{~cm}$. Secondly, they were boiled for $10 \mathrm{~min}$ and washed three times with distilled water. Finally, the carriers were dried overnight at $60^{\circ} \mathrm{C}$ and stored. Before biomass immobilization, the carriers were autoclaved at $121^{\circ} \mathrm{C}$, for $15 \mathrm{~min}$.

\subsection{Cells immobilization ability}

Cells immobilization into each carrier was correlated with two physicochemical properties, the water absorption index (WAI) and the critical humidity points (CHP). The ability to immobilize cells was determined based on the ratio between cells adhered and free cells suspended in the medium for each carrier. For WAI determination, $1.25 \mathrm{~g}$ of carrier, suspended in $15 \mathrm{~mL}$ of distilled water, was stirred with a glass rod, for $1 \mathrm{~min}$, at $25^{\circ} \mathrm{C}$. The carrier was afterwards centrifuged at $3000 \times \mathrm{g}$ for $10 \mathrm{~min}$, at $25^{\circ} \mathrm{C}$. After discarding the supernatant, the WAI was determined by the weight of the remaining residual water attached to the carriers and expressed as $\mathrm{g}_{\mathrm{H} 2 \mathrm{O}} \cdot \mathrm{g}_{\mathrm{DW}}{ }^{-1}$. CHP, given by the percentage of water contained in the carrier, was determined by measuring the difference in weight of $1 \mathrm{~g}$ of sample before and after $60 \mathrm{~min}$ in a thermobalance (Denver Instrument, Germany), at $120^{\circ} \mathrm{C}$ [29].

The immobilized biomass dried weight was determined based on the difference between the amount of cells and the carrier at the end of fermentation and the carrier itself before fermentation. The free cells concentration was determined by dry-weight. A $10 \mathrm{~mL}$ aliquot of fermentation medium was filtrated, at $0.2 \mu$ m cut-off, and dried at $105^{\circ} \mathrm{C}$, until constant weight. All assays were performed in triplicate.

\subsection{Dissolved oxygen determination}

The optical sensor Luminescent Dissolved Oxygen (LDO) connected to a measuring equipment HQ40d (Hach Lange) was used for the measurement of dissolved oxygen in the liquid fermentation medium. A volume of $100 \mathrm{~mL}$ of fermentation medium was transferred to the Erlenmeyer flasks $(500 \mathrm{~mL})$, containing the same $1 \mathrm{~g}$ of the carriers. The flasks were placed at $30^{\circ} \mathrm{C}$ during $63 \mathrm{~h}$. An air flow was sparged in the fermentation medium during $15 \mathrm{~min}$ and used as the $100 \%$ oxygen saturated reference. A control test, without carriers was also carried out. The dissolved oxygen was measured in each shaken-flask throughout the time-course.

\subsection{FOS production by immobilized cells}

A volume of $100 \mathrm{~mL}$ of fermentation medium, containing: $200 \mathrm{gL}^{-1}$ sucrose, $5.0 \mathrm{gL}^{-1} \mathrm{NaNO}_{3}, 4.0 \mathrm{gL}^{-1} \mathrm{KH}_{2} \mathrm{PO}_{4}, 0.5 \mathrm{gL}^{-1} \mathrm{KCl}$, $0.35 \mathrm{gL}^{-1} \mathrm{~K}_{2} \mathrm{SO}_{4}, 0.5 \mathrm{gL}^{-1} \mathrm{MgSO}_{4} \cdot 7 \mathrm{H}_{2} \mathrm{O}$ and $0.01 \mathrm{gL}^{-1} \mathrm{FeSO}_{4} \cdot 7 \mathrm{H}_{2} \mathrm{O}$, was transferred to a $500 \mathrm{~mL}$ Erlenmeyer flask, covered with a test tube aluminium cap, containing $1 \mathrm{~g}$ of each carrier. For fermentations using A3, A4 and A6, three units (half-size) of each carrier were used, and for A5 and S6, five units were used. The quantity of carrier used in the fermentation medium was determined so that the support occupies a volume of about $10 \%(\mathrm{v} / \mathrm{v})$ in relation to the 
fermentation medium contained in the flasks. The culture medium $\mathrm{pH}$ was adjusted to 5.5, before inoculation. Fermentations were performed at $28^{\circ} \mathrm{C}$, under $150 \mathrm{rpm}$ agitation, in an orbital shaker. Flasks containing the carriers were directly inoculated with $1 \mathrm{~mL}$ of the A. pullulans concentrated spores suspension $\left(9 \times 10^{7}\right.$ spores $\left.\mathrm{mL}^{-1}\right)$. Cells were immobilized in situ in the flasks, at the beginning of the fermentation, by natural adsorption to the immobilizing material, at $25^{\circ} \mathrm{C}$, according to the methodology described by Mussato et al. [23]. All reagents used were obtained from VWR (Belgium). The chemicals used were of analytical grade, except for sucrose used for FOS synthesis, which was a commercial sugar "Grand Pont", obtained by Raffinerie Tirlemontoise, S.A., Belgium. The fermentation broth composition used was based on our previous work [17]. Several samples were collected at different fermentation times, namely at $0,15,20,25,38,43$ and $63 \mathrm{~h}$, to determine sugar concentration profiles.

\subsection{Sugar analysis}

Samples collected during the fermentations were injected at $1 \mathrm{mLmin}^{-1}$ flow-rate in a HPLC (Jasco, France) coupled to a Prevail Carbohydrate ES 5 u column $(5 \mu \mathrm{m}, 25 \mathrm{~cm}$ length $\times 0.46 \mathrm{~cm}$ diameter) (Alltech, USA), working at room temperature, and a refractive index detector, working at $30^{\circ} \mathrm{C}$, for sugar analysis. The mobile phase used was a mixture of acetonitrile (HPLC Grade, Carlo Erba, France) in ultra-pure-water $\left(70: 30 \mathrm{v}_{\text {acetonitrile }} / \mathrm{v}_{\text {water }}\right)$, containing $0.04 \%(\mathrm{v} / \mathrm{v})$ of ammonium hydroxide in water (HPLC Grade, from Sigma, Germany) [17,30,31]. Chromatographic spectra were analysed using Star Chromatography Workstation software (Varian, USA).

FOS standards, namely 1-kestose $\left(\mathrm{GF}_{2}\right)$, nystose $\left(\mathrm{GF}_{3}\right)$ and 1 -fructofuranosylnystose $\left(\mathrm{GF}_{4}\right)$ were acquired from Wako (Chemicals $\mathrm{GmbH}$, Japan). Sucrose (GF) and fructose (F) standards were obtained from Merck (USA) and glucose (G) from VWR (Belgium).

\subsection{Statistical analysis}

The statistical data analysis was performed using SigmaPlot ${ }^{\circledR}$ version 11.0 through one-way analysis of variance (ANOVA) and Tukey's HSD (Honest Significant Difference) test at a 5\% level of significance. All the fermentations were performed in triplicate. The relation between the physicochemical parameters, WAI and $\mathrm{CHP}$, and the ability to immobilize cells, given by the amounts of immobilized and free cells, was studied using explorative principal component analysis (PCA) with R software (version 3.3.1).

\section{Results and discussion}

\subsection{Screening of carriers for Aureobasidium pullulans immobilization}

A screening of potential carriers of different materials, to be used in A. pullulans cells immobilization was proposed, aiming at improving the concentration, percentage and productivity of FOS produced through batch fermentations. Two physicochemical parameters, namely WAI and CHP, were determined for each carrier. The parameters were afterwards correlated with the amount of cells immobilized to the carrier and free cells in the medium (Table 1).

WAI represents the water that can be absorbed by the carrier and, is related to the carrier hydrophilic groups, which can bind water molecules that, in turn, will be available for the microorganism's growth and development. On the other hand, CHP represents the quantity of water linked to the carrier, which cannot be used for fungus growth $[20,26]$. When high proportion of water is bonded to the carrier material, the amount of free water for the microorganism's development is lower [25]. In this context, materials with high WAI or high water-content for microorganisms growth, and low CHP or low water-content linked to the material itself, are desirable for cells immobilization [20,26]. A maximum limit of $40 \%$ for CHP was recommended for Aspergillus niger in solid-state fermentations [32].

A wider range of WAI and CHP values and higher WAI values were herein obtained for the synthetic materials used, as compared to the agro-industrial or mineral ones (Table 1). Among the synthetic materials, the higher WAI values were found for fibre glass wool (S7) and polyester staple fibre (S8), followed by vegetal sponge (S3), reticulated polyurethane foam (diameter $=1 \mathrm{~mm}$ ) (S2) and vegetal scourer (S4), oscillating from 26.20 to $9.89 \mathrm{~g}_{\mathrm{H} 2 \mathrm{O}} \cdot \mathrm{g}_{\mathrm{DW}}$ class $=\ddot{\mathrm{x}} \mathrm{ps}$ thinspace $\ddot{>} \mathrm{g}_{\mathrm{H} 2 \mathrm{O}} \cdot \mathrm{g}_{\mathrm{DW}}{ }^{-1}$. The same materials presented the lowest CHP values, ranging between 13.38 and 40.19\%. Concerning the agro-industrial by-products, higher WAI and lower CHP values were found for mandarin peel (A1), banana peel (A2) and chestnut shell (A6), and similar values were found for walnut (A3), almond (A4) and pistachio (A5) shells.

The mineral carriers provided higher CHP values when compared to the other carrier types, although the WAI values showed to be similar to the ones obtained for the agro-industrial byproducts A3, A4 and A5. The range of values herein determined are comparable with the values reported in a study conducted by Mussatto et al. [23], particularly for the reticulated polyurethane foam (S2), where the WAI and CHP values obtained were $12.20 \mathrm{~g}_{\mathrm{H} 2 \mathrm{O}} \cdot \mathrm{g}_{\mathrm{DW}}{ }^{-1} \mathrm{~g}_{\mathrm{H} 2 \mathrm{O}} \cdot \mathrm{g}_{\mathrm{DW}}{ }^{-1}$ and $40 \%$, respectively. On the other hand, the WAI values for the vegetal fibre (S4) and pumice stone (M1) obtained in the same study were about 6.90 and $2.60 \mathrm{~g}_{\mathrm{H} 20} \cdot \mathrm{gDW}^{-1}, \mathrm{~g}_{\mathrm{H} 20} \cdot \mathrm{g}_{\mathrm{DW}}{ }^{-1}$, slightly different from those herein obtained, 9.89 and $1.77 \mathrm{~g}_{\mathrm{H} 2 \mathrm{O}} \cdot \mathrm{g}_{\mathrm{DW}}{ }^{-1}, \mathrm{~g}_{\mathrm{H} 2 \mathrm{O}} \cdot \mathrm{g}_{\mathrm{DW}}{ }^{-1}$, respectively. Both studies, obtained the lowest values for the vegetal fibre (S4), followed the reticulated polyurethane foam ones, and the pumice stone (M1).

Regarding the levels of WAI and CHP determined for the materials studied, the synthetic materials ones showed greater potential for cells immobilization, which growth is favoured by the higher content of water linked to the carrier structure (higher WAI).

Considering the immobilization ability, given by the amounts of free and immobilized cells, all the materials were able to immobilize $A$. pullulans cells to their structures, although with different ratios, as shown in Table 1. In general, synthetic materials showed greater immobilization potential as compared to the agro-industrial by-products and mineral materials, as it was suggested by the physicochemical parameters. S2, S7 and S8 immobilized higher amounts of cells (around $2.16 \pm 0.09 \mathrm{~g}_{\text {imob }} \cdot \mathrm{g}_{\text {carrier }}{ }^{-1}, \mathrm{~g}_{\text {imob }} \cdot \mathrm{g}_{\text {carrier }}{ }^{-1}$, in average) with lower levels of free cells in the medium (average $0.60 \pm 0.02 \mathrm{gL}^{-1}$ ), corresponding to up to $75 \%\left(\mathrm{~g}_{\text {immob }} \cdot \mathrm{g}_{\text {total }}{ }^{-1}\right)$ of the total cells in the medium, as it is possible to observe in Fig. 1.

The levels of immobilized and free cells in the medium, found in the present work, for polyurethane foam (S2), are similar to those obtained by Mussatto et al. [33] while using A. japonicus, namely, $1.98 \mathrm{~g}_{\text {imob }} \cdot \mathrm{g}_{\text {carrier }}{ }^{-1} \mathrm{~g}_{\text {imob }} \cdot \mathrm{g}_{\text {carrier }}{ }^{-1}$ and $0.61 \mathrm{gL}^{-1}$, respectively. Vegetal fibre scourer and polyurethane foam also obtained the greatest values for cells immobilization, as well pumice stone obtained the lowest ones in another work conducted by the same author [23].

Although with lower ability to immobilize cells by the agroindustrial by-products, compared to the synthetic ones, the shell residues (A3, A4, A5 and A6) showed better results of immobilization, $13.74 \pm 2.05 \%\left(\mathrm{~g}_{\text {immob }} \cdot \mathrm{g}_{\text {total }}{ }^{-1}\right)$ in average, than the peels (A1 and $\mathrm{A} 2), 1.22 \pm 0.10 \%\left(\mathrm{~g}_{\text {immob }} \cdot \mathrm{g}_{\text {total }}{ }^{-1}\right)$, in average (Fig. 1$)$. On the other hand, as compared to the synthetic materials, great concentrations of free cells were determined in these assays, mainly for $\mathrm{A} 1$ and $\mathrm{A} 2$ peels, where $54.74 \pm 8.09$ and $55.72 \pm 6.29 \mathrm{gL}^{-1}$ were 
Table 1

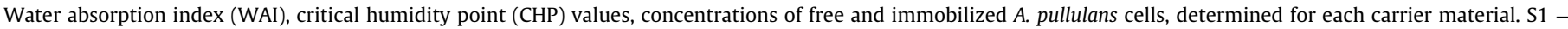

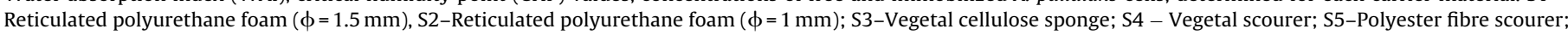

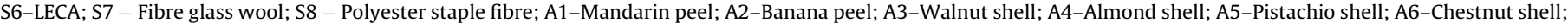
M1-Granular pumice stone; and M2-Granular natural mordenite zeolite. DW: Dried weight.

\begin{tabular}{|c|c|c|c|c|c|}
\hline & Code & $\begin{array}{l}\text { WAI } \\
\left(\mathrm{g}_{\mathrm{H} 2 \mathrm{O}} \cdot \mathrm{g}_{\mathrm{DW}}{ }^{-1}\right)\end{array}$ & $\begin{array}{l}\mathrm{CHP}(\%) \\
\left(\mathrm{g}_{\text {carrier }} \cdot \mathrm{g}_{\left.\text {carrier }+\mathrm{H}_{20} \mathrm{O}^{-1}\right)}\right.\end{array}$ & $\begin{array}{l}\text { Immobilized cells } \\
\left(\mathrm{g}_{\text {immob }} \cdot \mathrm{g}_{\text {carrier }}{ }^{-1}\right)\end{array}$ & $\begin{array}{l}\text { Free cells } \\
\left(\mathrm{g} \mathrm{L}^{-1}\right)\end{array}$ \\
\hline \multirow{8}{*}{ Synthetic products } & S1 & 5.87 & 50.03 & $1.88 \pm 0.38$ & $0.98 \pm 0.01$ \\
\hline & $\mathrm{S} 2$ & 12.54 & 40.19 & $2.20 \pm 0.25$ & $0.63 \pm 0.05$ \\
\hline & S3 & 12.88 & 24.53 & $1.39 \pm 0.03$ & $0.70 \pm 0.11$ \\
\hline & S4 & 9.89 & 23.92 & $1.58 \pm 0.21$ & $0.88 \pm 0.09$ \\
\hline & S5 & 7.63 & 42.57 & $1.44 \pm 0.03$ & $5.35 \pm 0.29$ \\
\hline & S6 & 1.99 & 50.09 & $1.03 \pm 0.02$ & $46.58 \pm 5.55$ \\
\hline & S7 & 26.20 & 13.38 & $2.00 \pm 0.13$ & $0.61 \pm 0.09$ \\
\hline & S8 & 26.07 & 39.65 & $2.30 \pm 0.13$ & $0.57 \pm 0.09$ \\
\hline Agro-industrial & $\mathrm{A} 1$ & 3.95 & 36.00 & $0.59 \pm 0.20$ & $54.74 \pm 8.09$ \\
\hline \multirow[t]{5}{*}{ by-products } & $\mathrm{A} 2$ & 3.30 & 42.73 & $0.77 \pm 0.04$ & $55.72 \pm 6.29$ \\
\hline & A3 & 1.73 & 46.09 & $1.05 \pm 0.02$ & $4.43 \pm 0.37$ \\
\hline & A4 & 1.51 & 49.40 & $0.97 \pm 0.01$ & $7.97 \pm 1.34$ \\
\hline & A5 & 1.63 & 47.25 & $0.99 \pm 0.01$ & $6.06 \pm 2.04$ \\
\hline & A6 & 3.10 & 45.08 & $1.13 \pm 0.09$ & $9.19 \pm 2.35$ \\
\hline \multirow[t]{2}{*}{ Mineral products } & M1 & 1.77 & 50.19 & $1.05 \pm 0.03$ & $8.28 \pm 0.96$ \\
\hline & M2 & 1.80 & 50.27 & $1.08 \pm 0.03$ & $9.11 \pm 1.67$ \\
\hline Control & & & & & $8.84 \pm 1.94$ \\
\hline
\end{tabular}

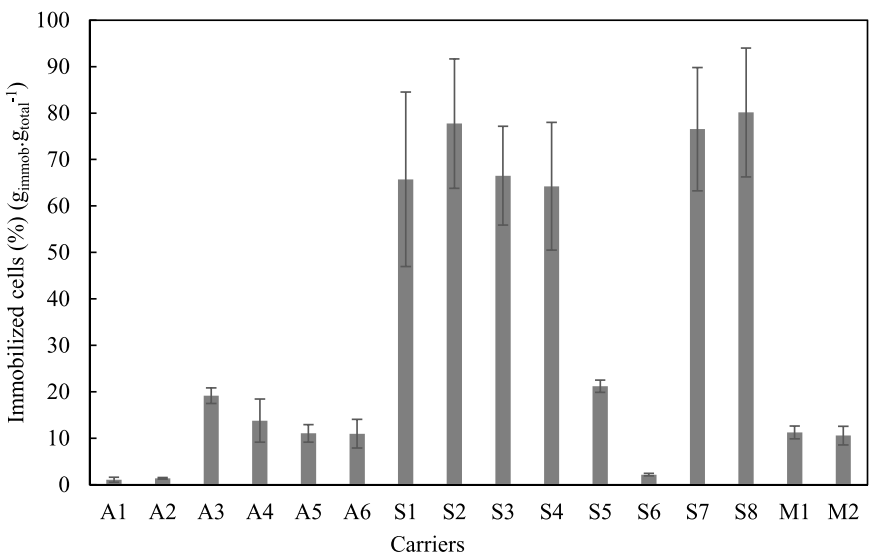

Fig. 1. Percentage of immobilized cells obtained at the end of the fermentation process for the carriers studied: $\mathrm{S} 1$ - Reticulated polyurethane foam $(\phi=1.5 \mathrm{~mm})$, S2-Reticulated polyurethane foam $(\phi=1 \mathrm{~mm})$; S3-Vegetal cellulose sponge; S4 Vegetal scourer; S5-Polyester fibre scourer; S6-LECA; S7 - Fibre glass wool; S8 - Polyester staple fibre; A1-Mandarin peel; A2-Banana peel; A3-Walnut shell; A4-Almond shell; A5-Pistachio shell; A6-Chestnut shell; M1-Granular pumice stone; and M2-Granular natural mordenite zeolite.

respectively obtained. These levels were much higher than the ones determined in the control, where cells were free in the medium $\left(8.84 \pm 1.94 \mathrm{gL}^{-1}\right)$. The significant difference obtained for A1 and A2, suggests that $A$. pullulans cells might have used these materials as both, attaching structures and nutrient sources, for their growth. Indeed, these materials have been used as immobilizing matrices in SSF fermentations, where generally they can perform both roles [34].

Different studies have also demonstrated that the roughness and porosity of the immobilizing structures promote a firmer attachment of cells to the material structures and reduce the detachment of immobilized cells, by the hydraulic shearing forces. In addition, the increased surface area of the material may favoured the immobilization $[14,35,36]$. In this context, the morphology of each carrier was studied by microscopic analysis, and the images collected are shown in Fig. 2. In general, the structures of the agro-industrial byproducts (inner and outer parts of the peel or shell) and the mineral materials showed a more compact morphology, with lower porosities and roughness as compared to the synthetic materials, which can explain the decreased capability to immobilize cells.
Carriers S1, S2, S3 and S4 have very porous structures with light weight, and presented similar abilities to immobilize A. pullulans cells, $68.55 \pm 3.38 \%\left(\mathrm{~g}_{\text {immob }} \cdot \mathrm{g}_{\text {total }}{ }^{-1}\right)$ in average, although, $\mathrm{S} 2$ showed to be quite more efficient in immobilizing cells, obtaining $77.74 \pm 13.93 \%$. The morphological structure of S5 showed to be less efficient to immobilize cells $\left(24.01 \pm 0.01 \%\right.$ ( $g_{\text {immob }} \cdot g_{\text {total }}$ $\left.{ }^{-1}\right)$ ). Carrier $\mathrm{S} 6$ is the less porous synthetic material studied, which explains its lowest ability to immobilize cells, namely $2.16 \pm 0.26 \%$ $\left(g_{\text {immob }} \cdot g_{\text {total }}{ }^{-1}\right)$. Finally, filamentous structures were found for carriers S7 and S8, which led to an efficient entrapment of cells with $76.54 \pm 13.28$ and $80.12 \pm 13.90 \%\left(\mathrm{~g}_{\text {immob }} \cdot \mathrm{g}_{\text {total }}{ }^{-1}\right)$ of total cells immobilized.

As shown in Table 1, in addition to the lower ability to immobilize cells, the S6 carrier (LECA) stimulated significantly the growth of free cells in the medium, up to $45.0 \mathrm{gL}^{-1}$, similarly to mandarin and banana peels (A1 and A2, respectively). LECA consists of small, lightweight, bloated particles of burnt plastic clay, which cannot act as a nutrient source, as occurred with the agro-industrial carriers A1 and A2. Therefore, the significant increase of free cells growth while using the $\mathrm{S} 6$ carrier, may be related to the shear stress caused in the cells, by the material itself. The same assumption may be used to justify the great amount of free cells found in the medium while using the mineral materials M1 and M2. Although these materials have a more favorable porous structure for cells immobilization, with immobilizing ability up to $10 \%\left(\mathrm{~g}_{\mathrm{immob}} \cdot \mathrm{g}_{\text {total }}{ }^{-1}\right)$, the amount of free cells determined was similar to the ones determined in the control, using free cells, $8.74 \pm 0.21 \mathrm{gL}^{-1}$ in average (Table 1 ). In order to address this issue, the dissolved oxygen in the medium was determined, in a set of experiments, as discussed in the next section.

\subsection{Dissolved oxygen time-course evolution}

The evolution of the dissolved oxygen, that is, the quantity of free, non-chemically combined, oxygen present, in the fermentation medium was followed in the shaken flasks containing the carriers that showed higher amounts of free cells in the medium, at the end of fermentation, but could not be used as nutrients source due to their nature, namely, S6, M1 and M2. A control experiment, where no carrier was added, was also performed. In addition, S2 was also used, to confirm the oxygenation level of the medium in the presence of this carrier. The results are shown in Fig. 3. A high decrease of the dissolved oxygen level occurred in the 

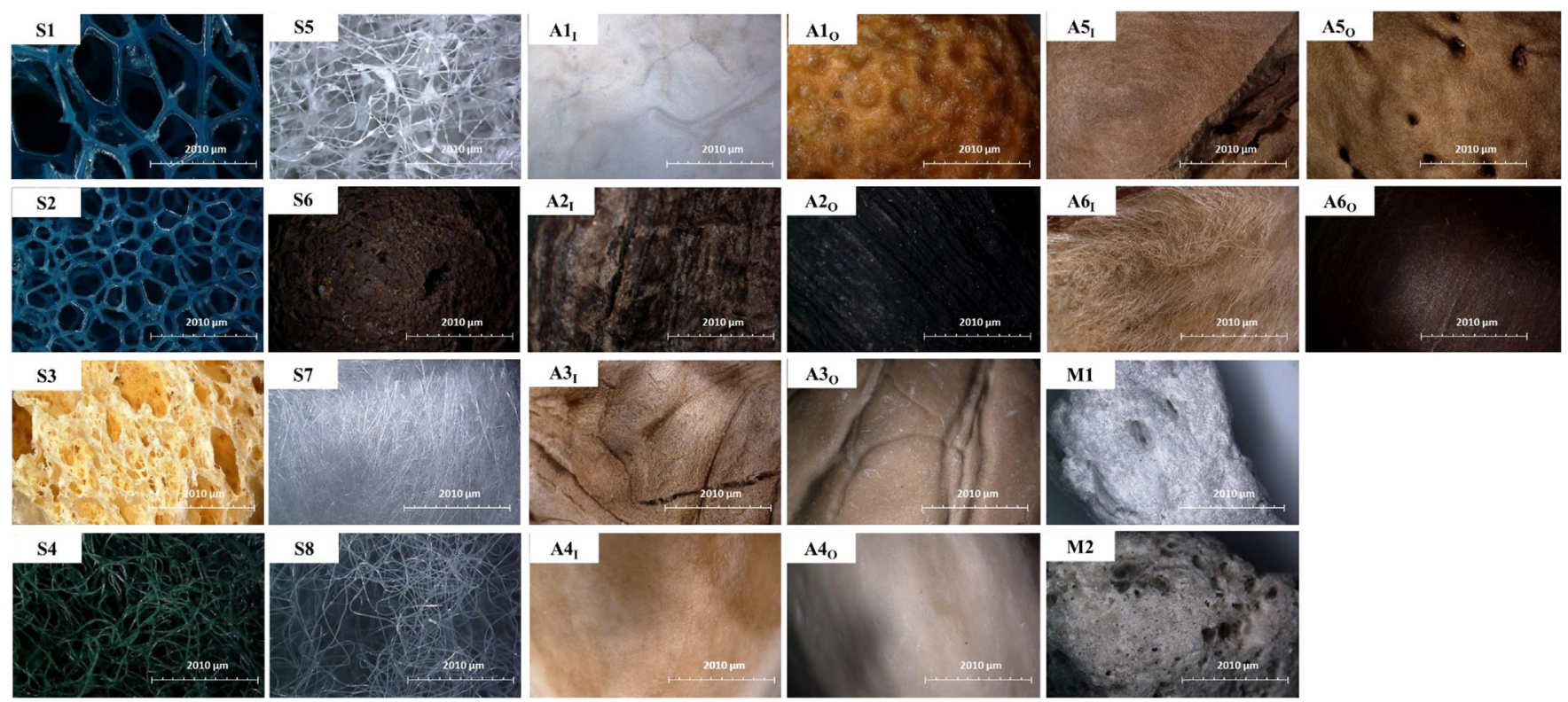

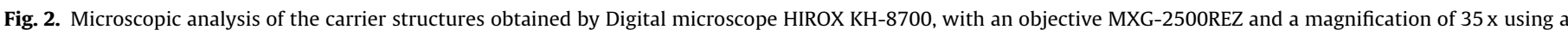

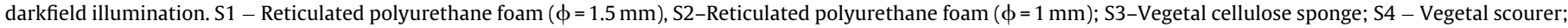

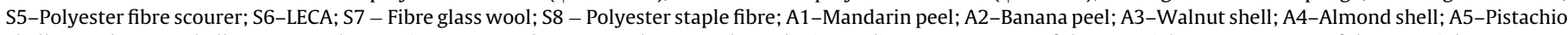
shell; A6-Chestnut shell; M1-Granular pumice stone; and M2-Granular natural mordenite zeolite. I - Inner part of the material; O - Outer part of the material.

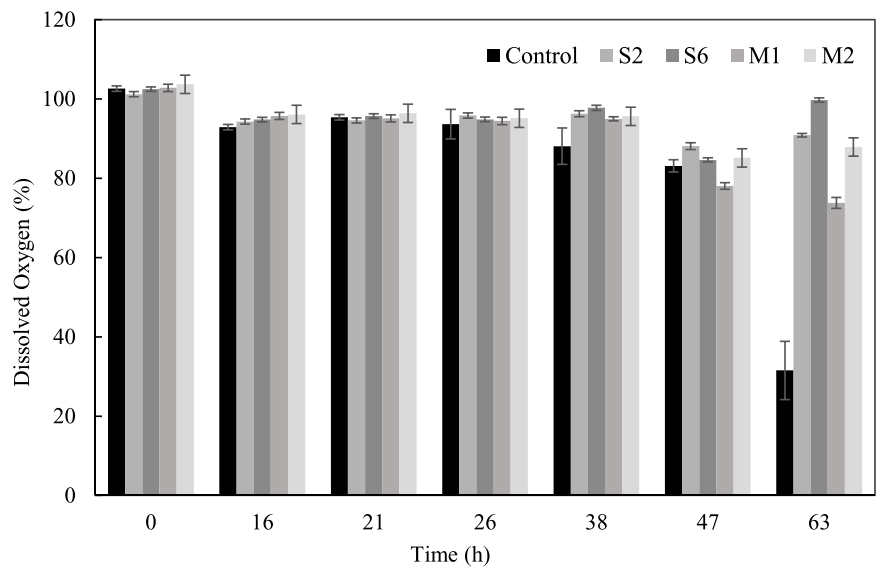

Fig. 3. Percentage of dissolved oxygen in the fermentation medium without carrier (control), and with the carriers S2-reticulated polyurethane foam $(\phi=1 \mathrm{~mm}), \mathrm{S} 6$ LECA, M1-granular pumice stone and M2-granular natural mordenite zeolite.

fermentation medium without carrier (control: black bars). After $63 \mathrm{~h}$ under $150 \mathrm{rpm}$ of agitation, the dissolved oxygen decreased from the saturation to $31.5 \pm 7.4 \%$. Similarly, at the same fermentation time, the dissolved oxygen also decreased in the experiments run with the mineral materials, although in much less level than in the control, $73.8 \pm 1.4$ for M1 and $87.9 \pm 2.0 \%$ for M2. The presence of the $\mathrm{S} 6$ carriers allowed to keep the percentage of dissolved oxygen in higher levels than the others, namely $95.7 \pm 5.2 \%$. For the S2 carrier, a constant and high amount of dissolved oxygen in the medium, $94.4 \pm 3.9 \%$, was as well observed. Regarding the immobilization ability of S2 and S6 carriers, it is possible to suggest that in the presence of S6, the dissolved oxygen was used the growth of the free cells in the medium (which reached $46.58 \pm 5.55 \mathrm{gL}^{-1}$, compared to $0.63 \pm 0.05 \mathrm{gL}^{-1}$ with S2), while in the presence of S2, the transference of the oxygen to the growth of the immobilized cells was facilitated by the higher pore size and roughness of the S2 matrix, compared to 56 , which had a direct impact on the amount of immobilized cells concentration $(2.11 \pm 0.92$ and $1.03 \pm 0.02$ for S2 and S6, respectively).
The presence of the carriers in the fermentation medium confirmed to clearly influence on the aeration regime [37]. The effect showed to be dependent on the carrier type. As a result, the cellular growth was significantly enhanced by the presence of the carrier S6 due to the increase on the oxygen dissolution, as it was observed in other studies $[38,39]$.

\subsection{Principal component analysis (PCA)}

A PCA analysis was carried out to understand the effect of the physicochemical parameters, CHP and WAI, on the immobilization ability of the agro-industrial by-products and synthetic material carriers. PCA is a mathematical procedure that transforms a number of (possibly) correlated variables (in this case, CHP, WAI, and free and immobilized cells), into a (smaller) number of uncorrelated variables, called principal components [40]. The first component reports the higher variability in the data, while the succeeding components report the remaining variability. According to this method, the scores and loadings are produced, corresponding respectively to, the relation between the samples (or carriers) in a principal component defined space and the relation between the variables studied [40]. Fig. 4 shows the PCA of the first two principal components, PC1 and PC2, correlating WAI, CHP, free and immobilized cells for the synthetic materials and agro-industrial by-products. The first two principal components, together explained $86.5 \%$ (PC$1: 64.8 \%$ and PC-2:21.7\%) and 96.1\% (PC-1: $86.8 \%$ and PC-2:9.3\%) of the variance for the synthetic materials, Fig. 4(a), and agroindustrial by-products, Fig. 4(b), respectively.

For the synthetic materials, the first component, the more relevant one, discriminates samples with higher values of WAI which obtained higher number of cells immobilized, and are placed in the right quadrants of the Figure, and samples with higher values of CHP that obtained higher amounts of free cells in the medium, and are placed in the left quadrants of the Figure. This observation confirms that, for the synthetic materials, the physicochemical parameters, WAI and CHP, can be used as an indication of the immobilization ability of the materials. The synthetic carriers that presented higher WAI values and increased ability to immobilize cells, namely reticulated polyurethane foam (diameter $1 \mathrm{~mm}$ ) (S2), vegetal cellulose 

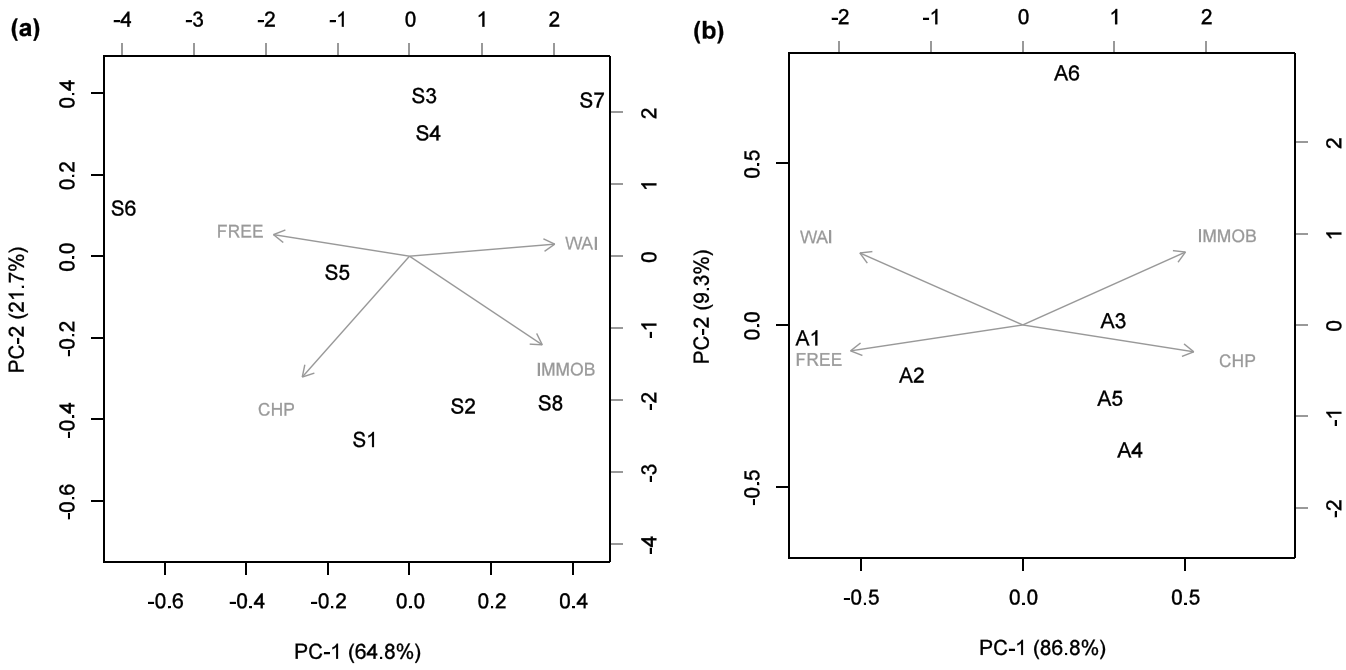

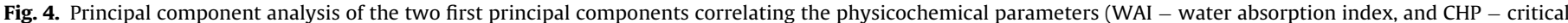

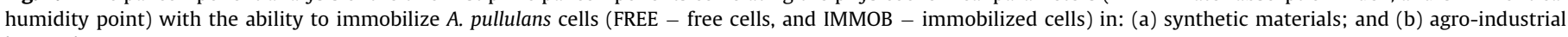
by-products.

sponge (S3), vegetal scourer (S4), fibre glass wool (S7) and polyester staple fibre (S8), were selected to immobilize A. pullulans to produce FOS.

On the other hand, according to Fig. 4(b), for the agro-industrial by-products, the ability to immobilize cells to the agro-industrial by-products matrices is not affected in the same way by the physicochemical parameters. These materials, presented low WAI values, compared to the synthetic ones, and showed structures less efficient for cells immobilization. Although, the higher WAI values found for the materials with higher amounts of free cells in the medium (mainly A1 and A2), had a great impact in the discrimination of the samples through PC-1 and PC-2. Carriers chestnut shell (A6), walnut shell (A3) and pistachio shell (A5), with high WAI values and immobilization ability were selected as potential agroindustrial by-products materials to immobilize A. pullulans cells for FOS production.

\subsection{FOS production by A. pullulans immobilized to the selected carriers}

FOS production by A. pullulans cells immobilized to the selected carriers was evaluated by batch fermentation. FOS concentration profiles throughout the fermentation were similar to all the conditions tested and regardless of the nature of the carrier, although with different maximal concentrations (Fig. 5(a) and (b)). The required time to achieve the maximum FOS production for each carrier tested and the control assay are resumed in Table 2, likewise the sugars composition, fermentation yield and productivity of FOS obtained.

The maximum FOS concentration was achieved at the same fermentation time $(36.0 \mathrm{~h})$ for assays using the A3, S3 and S8 carriers, as compared to the control, where cells are free in the medium (without carrier). For all the other carriers, this point was achieved faster, namely after $25.0 \mathrm{~h}$ (Fig. 5 and Table 2). The shorter time needed to achieve the maximal concentration of FOS when cells are immobilized, compared to the control, was already reported in several works $[14,23,41]$. Regarding the amount of FOS produced, the maximal concentration obtained was higher when using the agro-industrial by-products as carriers Fig. 5(a), and the use of the walnut shell (A3) and pistachio shell (A5) showed to increase significantly $(\mathrm{p}<0.05)$ the production of FOS, in comparison to the control $\left(92.09 \pm 9.73 \mathrm{gL}^{-1}\right)$. Among the synthetic materials selected, only the $S 2$ provided a statistically higher concentration of FOS $(p<0.05)$, as compared to the control (Fig. 5(b) and Table 2). The increased amount of FOS produced when using agro-industrial by-products, in comparison with the synthetic ones, can be related to the higher amount of free cells released in the medium for these assays, as it was discussed for Table 1. As the concentration of free cells is higher, increased levels of enzymes with transfructosylation activity are produced [10], whose release to the fermentation broth can be favoured by the abrasion effect caused by the carrier's structures [43]. The maximum amount of FOS obtained when using the reticulated polyurethane foam (S2), $108.17 \pm 8.83 \mathrm{gL}^{-1}$, was similar to the one obtained by Mussatto et al. (2009) with A. japonicus immobilized to the same adhering material [23] (110.3 $\left.\mathrm{gL}^{-1}\right)$, which was likewise reported as a suitable carrier for cells immobilization [44].

Simultaneously, the percentage of FOS obtained, given by the ratio between the maximal amount of FOS and the total sugars present in the medium, was higher, and statistically significant $(\mathrm{p}<0.05)$ when using the agro-industrial by-products (A3, A5 and A6) to immobilize the A. pullulans cells, as compared to the control $(39.75 \pm 0.54 \%(w / w))$. The synthetic carriers, with the exception of the carrier S3, provided as well an increased and statistically significant $(p<0.05)$ percentage of FOS in the medium, as compared to the control. The increased percentage of FOS obtained when cells grow attached to a carrier matrix can be related to the maintenance of their biological functions while increasing their stability, which may also enhance cells productivity, and thus, increase the concentration of cells attached to each carrier [45]. In addition, the immobilization of cells may reduce enzyme inhibition issues, related to the presence of specific products released in the medium [46], such as glucose, which is known to interfere in the FOS producing process [47]. It is also known that cells immobilization allows a more efficient transfer of nutrients and oxygen in the medium, as discussed above, which can increase the production rates of the final product [37]. Moreover, when cells are immobilized to a carrier, it can introduce a variation in the hydrodynamic conditions of the medium that may induce cells to develop unusual morphological forms attached to the carrier, as it was stated by Doran and Bailey [48]. These authors found that the metabolism of the immobilized cells is affected by the direct physical contact with a solid surface or polymer matrix, or with other cells.

The agro-industrial by-products provided as well higher yields of FOS. The carriers A3 and A5 obtained significantly higher yields as compared to the control. The synthetic materials, S2 and S8, provided also higher yields, although the differences found were not 

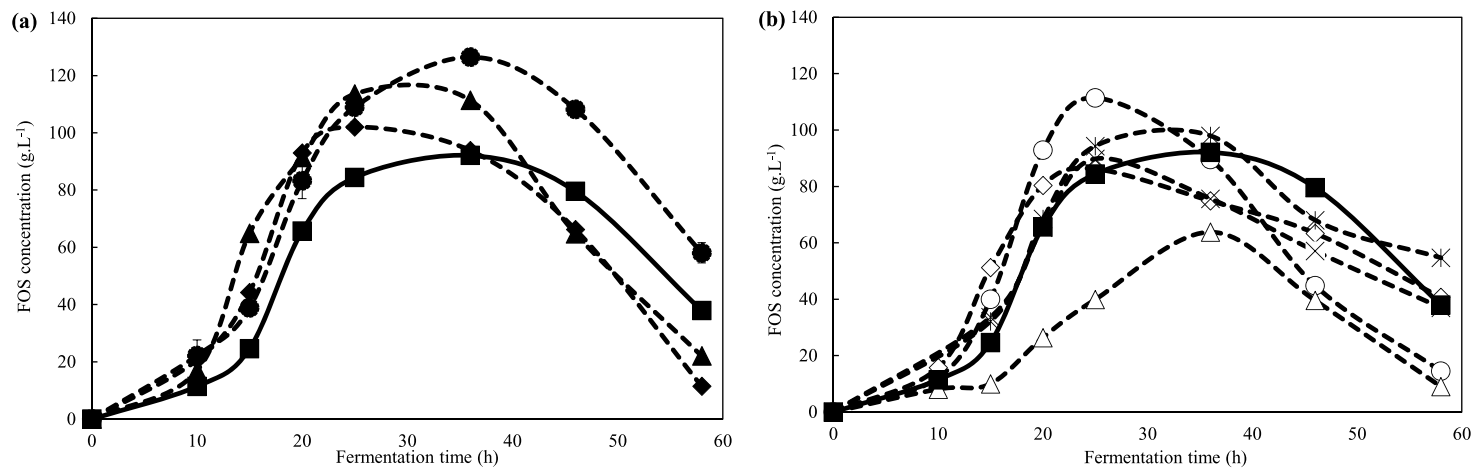

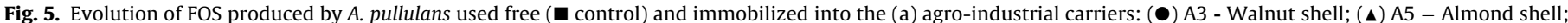

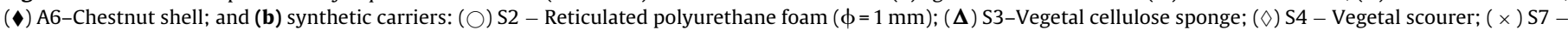
Fibre glass wool; (*) S8 - Polyester staple fibre.

Table 2

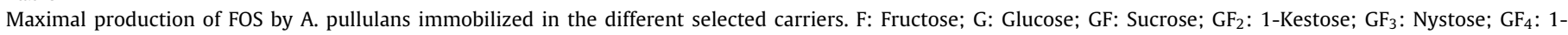

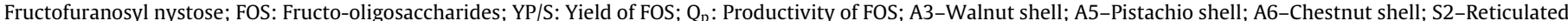
polyurethane foam ( $\phi=1 \mathrm{~mm})$; S3-Vegetal cellulose sponge; S4 - Vegetal scourer; S7 - Fibre glass wool; S8 - Polyester staple fibre. ${ }^{*}$ Results statistically significant.

\begin{tabular}{|c|c|c|c|c|c|c|c|c|c|c|c|}
\hline & $\begin{array}{l}\text { Time } \\
\text { (h) }\end{array}$ & $\begin{array}{l}\mathrm{F} \\
\left(\mathrm{g} . \mathrm{L}^{-1}\right)\end{array}$ & $\begin{array}{l}\text { G } \\
\left(\mathrm{g} . \mathrm{L}^{-1}\right)\end{array}$ & $\begin{array}{l}\text { GF } \\
\left(\mathrm{g} . \mathrm{L}^{-1}\right)\end{array}$ & $\begin{array}{l}\mathrm{GF}_{2} \\
\left(\mathrm{~g} . \mathrm{L}^{-1}\right)\end{array}$ & $\begin{array}{l}\mathrm{GF}_{3} \\
\left(\mathrm{~g} \cdot \mathrm{L}^{-1}\right)\end{array}$ & $\begin{array}{l}\mathrm{GF}_{4} \\
\left(\mathrm{~g} . \mathrm{L}^{-1}\right)\end{array}$ & $\begin{array}{l}\text { FOS } \\
\left(\mathrm{g} . \mathrm{L}^{-1}\right)\end{array}$ & $\begin{array}{l}\text { FOS } \\
(\%)\end{array}$ & $\begin{array}{l}Y_{\mathrm{P} / \mathrm{S}} \\
\left(\mathrm{gFOS} \cdot \mathrm{g}_{\mathrm{GF}, \mathrm{i}}{ }^{-1}\right)\end{array}$ & $\begin{array}{l}\mathrm{Q}_{\mathrm{p}} \\
\left(\mathrm{g}_{\mathrm{FOS}} \cdot \mathrm{L} \cdot \mathrm{h}^{-1}\right)\end{array}$ \\
\hline A3 & 36.0 & $30.49 \pm 6.52$ & $79.71 \pm 6.01$ & $18.66 \pm 7.19$ & $70.56 \pm 13.18$ & $50.20 \pm 0.07$ & $5.72 \pm 0.94$ & $\begin{array}{l}126.47 \pm 9.56 \\
*\end{array}$ & $\begin{array}{l}49.53 \pm 0.45 \\
*\end{array}$ & $\begin{array}{l}0.61 \pm 0.08 \\
*\end{array}$ & $3.51 \pm 0.93$ \\
\hline A5 & 25.0 & $20.76 \pm 5.02$ & $58.48 \pm 10.24$ & $33.11 \pm 26.04$ & $75.64 \pm 0.01$ & $34.17 \pm 1.27$ & $3.77 \pm 2.82$ & $\begin{array}{l}113.58 \pm 0.02 \\
*\end{array}$ & $\begin{array}{l}50.27 \pm 0.10 \\
*\end{array}$ & $\begin{array}{l}0.56 \pm 0.03 \\
*\end{array}$ & $\begin{array}{l}4.54 \pm 0.01 \\
*\end{array}$ \\
\hline A6 & 25.0 & $21.44 \pm 2.43$ & $55.62 \pm 5.13$ & $36.62 \pm 22.34$ & $76.51 \pm 7.18$ & $23.52 \pm 6.64$ & $2.00 \pm 0.72$ & $102.02 \pm 11.19$ & $47.30 \pm 0.76$ & $0.51 \pm 0.06$ & $4.08 \pm 1.83$ \\
\hline S2 & 25.0 & $31.53 \pm 4.70$ & $76.10 \pm 4.67$ & $34.47 \pm 7.36$ & $82.76 \pm 5.94$ & $24.27 \pm 8.02$ & $1.14 \pm 0.34$ & $\begin{array}{l}108.17 \pm 8.83 \\
*\end{array}$ & $\begin{array}{l}43.22 \pm 0.41 \\
*\end{array}$ & $0.52 \pm 0.05$ & $4.33 \pm 1.53$ \\
\hline S3 & 6.0 & $9.62 \pm 13.04$ & $94.08=$ & $22.4 \mathrm{~S}$ & 39.03 & $22.23 \pm$ & 2.02 & $63.82 \pm 3.53$ & $26.52 \pm 0.29$ & 0.2 & $1.77 \pm 0.17$ \\
\hline S4 & 25.0 & $24.74 \pm 3.38$ & $62.31 \pm 3.95$ & $29.07 \pm 5.34$ & $62.25 \pm 4.97$ & $23.10 \pm 2.56$ & $0.82 \pm 0.44$ & $86.17 \pm 4.95$ & $42.60 \pm 0.24$ & \pm 0.06 & $3.45 \pm 0.68$ \\
\hline S7 & 25.0 & $22.89 \pm 2.50$ & $60.26 \pm 3.85$ & $39.81 \pm 6.45$ & $69.60 \pm 1.45$ & $19.23 \pm 3.23$ & $0.93 \pm 0.22$ & $89.76 \pm 3.13$ & $42.20 \pm 0.22$ & $0.45 \pm 0.02$ & $3.59 \pm 0.45$ \\
\hline S8 & 36.0 & $31.50 \pm 3.04$ & $81.66 \pm 6.36$ & $21.04 \pm 5.23$ & $49.22 \pm 8.97$ & $44.74 \pm 7.19$ & $3.99 \pm 0.80$ & $97.95 \pm 9.10$ & $42.19 \pm 0.33$ & $0.49 \pm 0.00$ & $2.72 \pm 0.69$ \\
\hline Control & 36.0 & $30.99 \pm 4.09$ & $72.27 \pm 9.80$ & $36.30 \pm 15.64$ & $58.83 \pm 6.49$ & $30.82 \pm 6.78$ & $2.43 \pm 1.10$ & $92.09 \pm 9.73$ & $39.75 \pm 0.54$ & $0.46 \pm 0.05$ & $2.56 \pm 0.69$ \\
\hline
\end{tabular}

statistically significant $(\mathrm{p}>0.05)$ as compared to the control. The FOS productivities obtained through fermentation using immobilized cells to the selected carriers were higher than in the control, with the exception of carrier S3, although, only A5 showed a statistical relevance (Table 2 ).

According to the results obtained in the present work, concerning the concentration, percentage and yield of FOS obtained for the carriers selected, walnut shell (A3) and reticulated polyurethane foam (S2) were found to be the most suitable carriers to be further used in bio-reactor fermentation. For the two materials selected, A3 and S2, respectively, an increment of 27 and $15 \%(w / w)$ on the maximum concentration, 10 and $8 \%(\mathrm{w} / \mathrm{w})$ on the percentage of FOS in the medium, and around 25 and $12 \%(w / w)$ on the yield of FOS were achieved, as compared to the control. Fig. 6 shows the kinetics of the mono- and di-saccharides, fructose (F), glucose (G) and sucrose (GF) (Fig. 6(a) and (c)), and FOS, 1-kestose $\left(\mathrm{GF}_{2}\right)$, nystose $\left(\mathrm{GF}_{3}\right)$, and 1fructofuranosylnystose $\left(\mathrm{GF}_{4}\right)$ (Fig. 6(b) and (d)). Comparing Fig. 6(b) and $(\mathrm{d})$, it is possible to observe that by increasing the fermentation time, the transfructosylation reactions for the synthesis of $\mathrm{GF}_{2}, \mathrm{GF}_{3}$ and $\mathrm{GF}_{4}$ by fructotransferase (FTase) and the hydrolyzing reactions for the sucrose and FOS hydrolysis by fructofuranosidase (FFase) occur simultaneously, with an increased rate when $A$. pullulans are immobilized to A3 or S2, compared to the control. In Fig. 5(a) and (c), sucrose concentration decreases with time to a residual concentration, while fructose and glucose concentrations increase. An important hydrolysis effect can be observed while using the S2 (Fig. 6(a) and (b)), as compared to A3 (Figs. 6(c) and 5(d)) and the control experiments, which can be observed by the faster decrease of GF, and FOS, and the consequent increase of G and F concentrations. Glucose and fructose concentrations obtained in the presence of the carriers were higher than the control, and the maximal values were found using S2, namely $97.53 \pm 2.27$ and $82.47 \pm 5.87 \mathrm{gL}^{-1}$, respectively. The higher accumulation of both small saccharides under this condition suggests the occurrence of an inhibitory effect by glucose, which decreases the FTase activity, responsible for the linkage of fructose to the subsequent polysaccharide [46]. After $25 \mathrm{~h}$ of fermentation, the $\mathrm{GF}_{2}$ concentration decreases due to the gradual conversion to $\mathrm{GF}_{3}$ and the simultaneous hydrolysis, which begins earlier when using the S2 as compared to the A3 and the control. This effect is less important when using the carrier A3, as the production of glucose is slower and the concentrations lower. Under this condition, it is important to refer that the concentration of free cells was higher, leading to an increased transfructosylating activity that can as well explain the lower inhibitory impact.

In future work, it would be interesting to explore the potential of the walnut shell and reticulated polyurethane foam, both recyclable and low-cost materials in a scaled-up FOS production process, either in repeated cycle fermentations or in co-culture with other microorganisms to improve FOS productivity.

\section{Conclusions}

A. pullulans was successfully immobilized into all carriers studied, independently on the carrier nature: synthetic materials, agro-industrial by-products and mineral materials, although with different levels of adherence. The physicochemical parameters studied, WAI and CHP, showed to influence cells adherence to the structure of the carrier, mainly for the synthetic materials. For higher WAI and lower CHP levels, higher amounts of immobilized cells were respectively observed. High porosities and roughness were found for the synthetic carriers, which resulted in higher cell immobilization, notably for reticulated polyurethane foam, 

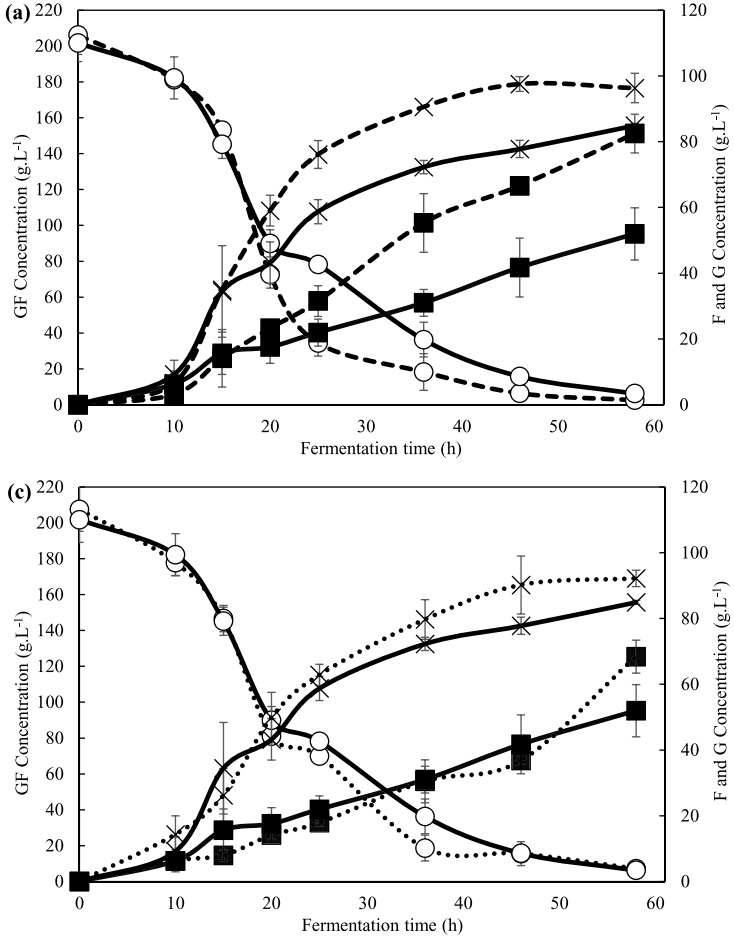
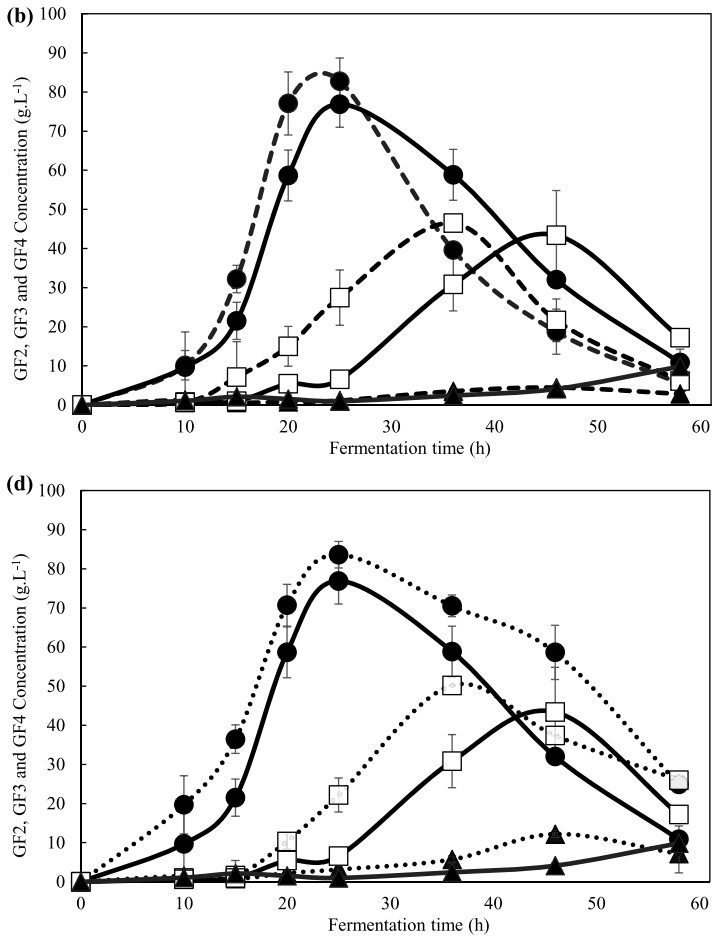

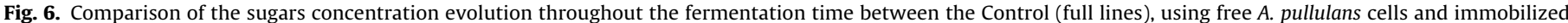

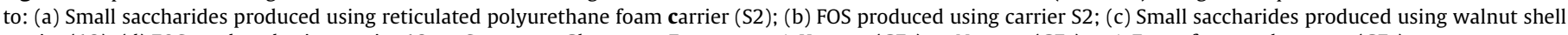

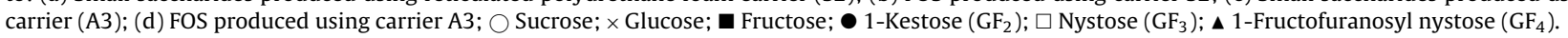

fibre glass wool and polyester staple fibre. Shear stress effect and dissolved oxygen were increased using LECA, pumice stone and zeolite, resulting in a higher free cells concentration. Mandarin and banana peels were not efficient immobilizing cells and acted as substrate source for cells growing.

The immobilization of cells allowed to obtain higher FOS productivity, compared to the use of free cells, mainly when using the agro-industrial by-products. Among the synthetic materials, the reticulated polyurethane foam was able to immobilize up to $75 \%\left(\mathrm{~g}_{\text {immob }} \cdot \mathrm{g}_{\text {total }}{ }^{-1}\right)$ of cells and increased the FOS concentration, yield and purity in 15,12 and $8 \%(\mathrm{w} / \mathrm{w})$, respectively, compared to the control. Besides the lower immobilization ability found for the walnut shell, which was less than $20 \%(w / w)$, the highest FOS productivity was found for this material, with an increase of $27 \%$ $(\mathrm{w} / \mathrm{w})$ in FOS concentration, $25 \%(\mathrm{w} / \mathrm{w})$ in FOS yield and 10\% (w/w) in FOS purity, compared to the control.

According to the results obtained in the present work, the use of walnut shell and reticulated polyurethane foam as recyclable and low-cost carriers to immobilize A. pullulans for FOS production in a scaled-up process is encouraged. The valorisation of the agro-industrial by-product walnut shell as carrier, showed to be an interesting alternative for the process, able to increase FOS productivity.

\section{Acknowledgements}

The author Cristiana C. Castro gratefully acknowledges the financial support from the F.R.S.-FNRS (Fonds de la Recherche Scientifique); FCT (Fundação para a Ciência e Tecnologia) F.R.S.FNRS, The Belgium National Fund for Scientific Research [PDR: T.0196.13]. Clarisse Nobre acknowledges the Portuguese Foundation for Science and Technology (FCT) for the Post-Doc Grant received [SFRH/BPD/87498/2012] and the strategic funding of UID/BIO/04469/2013 unit, COMPETE 2020 [POCI-01-0145-FEDER006684] and BioTecNorte Operation (NORTE-01-0145-FEDER-
000004) funded by European Regional Development Fund under the scope of Norte2020 - Programa Operacional Regional do Norte.

\section{References}

[1] S. Furusaki, M. Seki, Use and engineering aspects of immobilized cells in biotechnology, Adv. Biochem. Eng. Biotechnol. 46 (1992) 161-185.

[2] M.J. Nunez, J.M. Lema, Cell immobilization: application to alcohol production, Enzyme Microb. Technol. 9 (1987) 642-651.

[3] J.F. Liang, Y.T. Li, V.C. Yang, Biomedical application of immobilized enzymes, J. Pharm. Sci. 89 (2000) 979-990.

[4] M.B. Cassidy, H. Lee, J.T. Trevors, Environmental applications of immobilized microbial cells: a review, J. Ind. Microbiol. 16 (1996) 79-101.

[5] S.F.D. Souza, Trends in immobilized enzyme and cell technology, Indian J. Biotechnol. 1 (2002) 321-328.

[6] R.H. Wijffels, R.M. Buitelaar, C. Bucke, J. Tramper, Immobilized cells: basics \& applications, Prog. Biotechnol. Editorial, Amsterdam (1996).

[7] P.A.A. Coussement, Nutritional and health benefits of inulin and oligofructose inulin and oligofructose: safe intakes and legal status, J. Nutr. (1999) 1412-1417.

[8] A. Franck, Technological functionality of inulin and oligofructose, Br. J. Nutr. 87 (2007) 287-291

[9] C. Nobre, J.A. Teixeira, L.R. Rodrigues, New trends and technological challenges in the industrial production and purification of fructo-oligosaccharides, Crit. Rev. Food Sci. Nutr. 55 (2015).

[10] M.A. Ganaie, H.K. Rawat, O.A. Wani, U.S. Gupta, N. Kango, Immobilization of fructosyltransferase by chitosan and alginate for efficient production of fructooligosaccharides, Process Biochem. 49 (2014) 840-844.

[11] K.H. Jung, J.W. Yun, K.R. Kang, J.Y. Lim, J.H. Lee, Mathematical model for enzymatic production of fructo-oligosaccharides from sucrose, Enzyme Microb. Technol. 11 (1989) 491-494, http://dx.doi.org/10.1016/01410229(89)90029-X.

[12] A. Dominguez, C. Nobre, L.R. Rodrigues, A.M. Peres, D. Torres, I. Rocha, N. Lima, J.A. Teixeira, New improved method for fructooligosaccharides production by Aureobasidium pullulans, Carbohydr. Polym. 89 (2012) 1174-1179.

[13] C.-S. Chien, W.-C. Lee, T.-J. Lin, Immobilization of Aspergillus japonicus by entrapping cells in gluten for production of fructooligosaccharides, Enzyme Microb. Technol. 29 (2001) 252-257.

[14] Y. Cohen, Biofiltration - the treatment of fluids by microorganisms immobilized into the filter bedding material: a review, Bioresour. Technol. 77 (2001) 257-274.

[15] R. Cruz, V.D. Cruz, M.Z. Belini, J.G. Belote, C.R. Vieira, Production of fructooligosaccharides by the mycelia of Aspergillus japonicus immobilized in calcium alginate, Bioresour. Technol. 65 (1998) 139-143. 
[16] Y. Yang, J. Wang, D. Teng, F. Zhang, Preparation of high-purity fructo-oligosaccharides by Aspergillus japonicus $\beta$-fructofuranosidase and successive cultivation with yeast, J. Agric. Food Chem. 56 (2008) 2805-2809.

[17] C. Nobre, C.C. Castro, A.-L. Hantson, J.A. Teixeira, G. De Weireld, L.R. Rodrigues, Strategies for the production of high-content fructo-oligosaccharides through the removal of small saccharides by co-culture or successive fermentation with yeast, Carbohydr. Polym. 136 (2016) 274-281.

[18] M. Crittenden, R. Playne, Purification of food-grade oligosaccharides using immobilised cells of Zymomonas mobilis, Appl. Microbiol. Biotechnol. 58 (2002) 297-302.

[19] C. Nobre, C.C. Castro, A.-L. Hantson, J.A. Teixeira, L.R. Rodrigues, G. De Weireld, Production of high-content fructooligosaccharides, Int. J. Biol. Food Vet. Agric. Eng. 9 (2015).

[20] M.C. Orzua, S.I. Mussatto, J.C. Contreras-Esquivel, R. Rodriguez, H. de la Garza, J. a. Teixeira, C.N. Aguilar, Exploitation of agro industrial wastes as immobilization carrier for solid-state fermentation, Ind. Crops Prod. 30 (2009) 24-27.

[21] S.I. Mussatto, J.A. Teixeira, Increase in the fructooligosaccharides yield and productivity by solid-state fermentation with Aspergillus japonicus using agro-industrial residues as support and nutrient source, Biochem. Eng. J. 53 (2010) 154-157.

[22] M.A. Ganaie, L.K. Pathak, U.S. Gupta, Production of fructooligosaccharides by Aureobasidium pullulans using immobilization technique, J. Food Technol. 9 (2011) 91-94.

[23] S.I. Mussatto, C.N. Aguilar, L.R. Rodrigues, J.A. Teixeira, Colonization of Aspergillus japonicus on synthetic materials and application to the production of fructooligosaccharides, Carbohydr. Res. 344 (2009) 795-800.

[24] F. Mavituna, Pre-formed carriers for cell immobilisation, in: V. Nedović, R. Willaert (Eds.), Fundam. Cell Immobil. Biotechnol., Springer, Netherlands, 2004, pp. 121-139.

[25] S. Manpreet, S. Sawraj, D. Sachin, S. Pankaj, U.C. Banerjee, Influence of process parameters on the production of metabolites in solid-state fermentation, Malalaysian J. Microbiol. 1 (2005) 1-9.

[26] A. Robledo, A. Aguilera-Carbó, R. Rodriguez, J.L. Martinez, Y. Garza, C.N. Aguilar, Ellagic acid production by Aspergillus niger in solid state fermentation of pomegranate residues, J. Ind. Microbiol. Biotechnol. 35 (2008) 507-513.

[27] L.A. Pfaltzgraff, M. De Bruyn, E.C. Cooper, V. Budarin, J.H. Clark, Food waste biomass: a resource for high-value chemicals, Green Chem. 15 (2013) 307-314.

[28] U. Smolinska, B. Kowalska, W. Kowalczyk, M. Szczech, The use of agro-industrial wastes as carriers of Trichoderma fungi in the parsley cultivation, Sci. Hortic. (Amsterdam). 179 (2014) 1-8.

[29] W. Horwitz, Official methods of analysis of the association of official agriculture chemistry, AOAC Assoc. Off. Anal. Chem. Washington (1980).

[30] L.G. Dias, A.C.A. Veloso, D.M. Correia, O. Rocha, D. Torres, I. Rocha, L.R. Rodrigues, A.M. Peres, UV spectrophotometry method for the monitoring of galacto-oligosaccharides production, Food Chem. 113 (2009) 246-252.

[31] C. Nobre, M.J. Santos, A. Dominguez, D. Torres, O. Rocha, A.M. Peres, I. Rocha, E.C. Ferreira, J.A. Teixeira, L.R. Rodrigues, Comparison of adsorption equilibrium of fructose, glucose and sucrose on potassium gel-type and macroporous sodium ion-exchange resins, Anal. Chim. Acta 654 (2009) 71-76.

[32] M. Moo-Young, A.R. Moreira, R.P. Tengerdy, Principles of solid substrate fermentation. The filamentous fungi, in: J.E. Smith, D.R. Berry, B. Kristiansen (Eds.), Fungal Technol., Edward-Arnold, London, 1983, pp. 117-143.
[33] S.I. Mussatto, M.B. Prata, L.R. Rodrigues, J.A. Teixeira, Production of fructooligosaccharides and (-fructofuranosidase by batch and repeated batch fermentation with immobilized cells of Penicillium expansum, Eur. Food Res. Technol. 235 (2012) 13-22.

[34] S. Rodríguez-Couto, Exploitation of biological wastes for the production of value-added products under solid-state fermentation conditions, Biotechnol. J. 3 (2008) 859-870.

[35] M. Quirynen, C.M.L. Bollen, The influence of surface roughness and surface-free energy on supra- and subgingival plaque information in man, J. Clin. Periodontol. 22 (1995) 1-14.

[36] C. Guimarães, C. Matos, J. Azeredo, M. Mota, R. Oliveira, The importance of the morphology and hydrophobicity of different carriers on the immobilization and sugar refinery effluent degradation activity of Phanerochaete chrysosporium, Biotechnol. Lett. 24 (2002) 795-800.

[37] H.A. El-Enshasy, M.A., Farid, A.I. El-Diwany, Immobilized Cells - Basics and Applications, Proceedings of an International Symposium organized under auspices of The Working Party on Applied Biocatalysis of the European Federation of Biotechnology Noordwijkerhout, Elsevier (1996).

[38] S.E. Cowan, E. Gilbert, D. Liepmann, J.D. Keasling, Commensal interactions in a dual-species biofilm exposed to mixed organic compounds, Appl. Environ. Microbiol. 66 (2000) 4481-4485.

[39] P. Stoodley, I. Dodds, J.D. Boyle, H.M. Lappin-Scott, Influence of hydrodynamics and nutrients on biofilm structure, J. Appl. Microbiol. Symp. Suppl. (1999) 19-28.

[40] H. Abdi, L.J. Williams, Principal component analysis, Wiley Interdiscip. Rev. Comput. Stat. 2 (2010) 433-459.

[41] J.C. Santos, S.S. Silva, S.I. Mussatto, W. Carvalho, M.A.A. Cunha, Immobilized cells cultivated in semi-continuous mode in a fluidized bed reactor for xylitol production from sugarcane bagasse, World J. Microbiol. Biotechnol. 21 (2005) 531-535.

[42] S.I. Mussatto, C.N. Aguilar, L.R. Rodrigues, J.a. Teixeira, Fructooligosaccharides and (-fructofuranosidase production by Aspergillus japonicus immobilized on lignocellulosic materials, J. Mol. Catal. B Enzym. 59 (2009) 76-81.

[43] N.R. Mohamad, N.H.C. Marzuki, N.A. Buang, F. Huyop, R.A. Wahab, An overview of technologies for immobilization of enzymes and surface analysis techniques for immobilized enzymes, Biotechnol. Biotechnol. Equip. 29 (2015) 205-220.

[44] T. Romaškevič, S. Budriené, K. Pielichowski, J. Pielichowski, Application of polyurethane-based materials for immobilization of enzymes and cells: a review, Chemija 17 (2006) 74-89.

[45] M. Fenice, R. Di Giambattista, E. Raetz, J.L. Leuba, F. Federici, Repeated-batch and continuous production of chitinolytic enzymes by Penicillium janthinellum immobilised on chemically-modified macroporous cellulose, J. Biotechnol. 62 (1998) 119-131.

[46] S. Nikolic, L. Mojovic, M. Rakin, D. Pejin, Bioethanol production from corn meal by simultaneous enzymatic saccharification and fermentation with immobilized cells of Saccharomyces cerevisiae var. ellipsoideus, Fuel 88 (2009) 1602-1607.

[47] J.W. Yun, M.G. Lee, S.K. Song, Batch production of high-content fructo-oligosaccharides from sucrose by the mixed-enzyme system of (-fructofuranosidase and glucose oxidase, J. Ferment. Bioeng. 77 (1994) 159-163.

[48] P.M. Doran, J.E. Bailey, Effects of the immobilization on growth fermentation properties, and macromolecular composition of Saccharomyces cerevisiae attached to gelatin, Biotechnol. Bioeng. 28 (1986) 73-87. 